\title{
The effect of municipal wastewater on soil chemical properties
}

Mohsen Irandoost, Ali Salehi Tabriz

5 Department of Water Engineering, Kerman branch, Islamic Azad University, Kerman, Iran Corresponding author:Mohsen Irandoost(Irandostmo@gmail.com)

\begin{abstract}
The most important concern of the authorities in reuse of wastewater through artificial recharge of aquifers, drinking water and water used in agricultural exchange or direct use treated wastewater for health expenditures in different regions of the world, experience has resulted in effluent into account as a reliable source of water to supply the cities considered any parts of the world to supply water to cities and centers of population.In this direction the use of methods based on low quality irrigation water such as wastewater is a practical and convenient solution.The waste can be a rich source of minerals and organic be considered in order to the fertile soil.In the present study in order to assess the effects of wastewater, sewage refined Shiraz on soil chemical properties were analyzed in depth measurement.All samples from the middle of each plot at depths of 0-30 and 30-60 centimeter and also tested in a randomized complete block design with 3 replications. The results showed a decrease in acidity, salinity, phosphorus, nitrogen and heavy metals concentration in soil irrigated with waste water in the soil is irrigated with well water.
\end{abstract}

KEY WORDS: wastewater, soil chemical properties, the depth measurement

\section{INTRODUCTION}

The population growth rate is estimated to average about 7.1 percent (Liaqat and Zamyady, 2005).According to estimates, every year 100 million people, or in other words per second more than three people added to the world population.According to the forecasts, in 2025 the world's population of 8.5 billion will go beyond border. Meet the needs of a growing population, The food can be considered a major problem for many nations (Aggelides and Londra, 2000). In developing countries, the increasing need for fresh water in agricultural production is not limited to,But needs per person and also supplies the needed water resources industry needs and priorities of the urban communities in these areas.

Existence large population centers and industrial centers in the vicinity of freshwater resources according to the prioritization

30 of municipal and industrial water supply, the share of agriculture in reduced access to these resources (Abedi and Najafi, 2001) These factors have led to the idea of planning to provide new sources of water. Economic resources and in agricultural development and food security needs effectively circulate(Najafi et al., 2007 ; Salemi and Musharraf,2006)

If good quality water is scarce, water is considered low quality (Pescod ,1992). The effluent from the wastewater treatment feasibility portion of these resources includeBecause municipal population growth on the one hand and higher levels of public health on the other hand, increased water consumption and high water consumption will have to increase the amount of waste (Rezapour et al., 2012).On the other hand the release of raw sewage in nature and polluting the environment can affect the quality of surface and groundwater flows (Abedikoopayee et al., 2003; karimzadeh et al., 2012).While preserving the environment makes utilization of sewage water treatment, recovery and recycling of water is consumed.As a result, use of treated wastewater in agriculture reduces the use of the waters, which in addition to other uses, such as agriculture-could

40 be drinking (Alikhales and Smalzadeh, 2010). The low cost of using treated wastewater for irrigation, groundwater and surface water pollution reduction and reduce the cost of chemical fertilizers in agriculture are other advantages of using treated wastewater (Aiello et al.,2007) The treated wastewater in irrigation water volume required to include a small amount, but this amount makes use of waters with higher quality can be more important in the application (Asgharzadih,2012). The correct exploitation of municipal waste will reduce surface water pollution problemAnd not only saves water, but also due to the material and is very useful nutrient for plant growth (Gamito et al., 1999). The availability of this waste near urban centers around these areas provide the potential to increase agricultural production makes (Karak et al.,2012). Today regarding dry spells in Iran, the growing population, urbanization and industrialization, use of treated wastewater as a source of sustainable agriculture is (Salehi, 2010 ; Singh and Bahati,2003).

50 Since the wastewater cycle can be used to increase the pollution of groundwater aquifers, Therefore, in recent years in and out of the water purification project gathered outside urban areas is running.t seems that if chemical and biological wastewater pollution problems in food production and soil health not bring, can be used for crop production (Song et al.,2006 ; Soudakoure et al., 2013 ; Xu et al., 2010).With an average annual rainfall of 243 Fars province with more than 15 thousand hectares of cultivated area with limited water resources.One of the city's unconventional water resources, municipal wastewater treatment plant, which since 1386 has started to collect and wastewater treatmentAnd has about 52 thousand subscribers have joined the system. It is anticipated that this plant until 1405 to reach full operation and the effluent reaches the 69.5 million cubic meters per year (Tqvayyan and Alizadeh, 2007 ; Ghanbari et al.,2006).However due to above, it seems that waste water can be treated wastewater, as a reliable source of supply of water, especially in arid and semiarid regions, which are facing a severe shortage of water resources used.If the wastewater is used for irrigation of agricultural lands, Can be taken to save water and fertilizer and also reduce the cost of water supply big step up(Sepaskhah and Kariz,2011; RohaniShahraki, 2005). Therefore this study was to evaluate the quality of effluent from wastewater treatment plants and Shiraz 
Solid Earth Discuss., doi:10.5194/se-2017-6, 2017

Manuscript under review for journal Solid Earth

Published: 6 February 2017

(c) Author(s) 2017. CC-BY 3.0 License.

effluent quality parameters and standards, as well as to determine the rate of change of the elements and parameters to control soil is tested at different depths.

\section{Materials and methods}

5 In order to evaluate the effect of treated wastewater the city on the chemical properties of the soil, ground-based experiment with dimensions $8 \times 6 \mathrm{~m}$, In a randomized complete block design with three replications and in non-crop plant, carried out in 1392.Land the city water treatment plant was 200 meters. After leveling the ground, the plot of which was a $2 \times 2$ meters.According to that there are three replicates of each treatment, total plot was tested 9 Crete.

In this study, irrigation water quality experimental plots were two projects were considered as the main cause. Measuring the

10 depth of soil chemical parameters that apply to $30-0$ and $60-30 \mathrm{~cm}$ of the soil surface, this research were the subplots.It must be noted that the quality of water entering the experimental plots are as follows:

Treatment A: Well water (Well water quality is explained below) and treatment B: municipal wastewater.

The study to determine the long-term effects of wastewater on soil chemical properties evaluated, the number of different treatments on the ground 15 times, and an interval of 7 days compared to each other.Water and wastewater, as well as input from each treatment were similar to experimental plots.Before applying the irrigation to measure physical and chemical parameters of ground, from the depths of 0-30 and 30-60 cm soil samples were taken from the middle of each plot and soil and water samples for lab analysis fee of Agriculture and Natural Resources Research Institute in Shiraz was sent. The results of chemical analysis of soil texture and soil are important elements in Tables 1 and 2 are provided.

Also before the test to measure chemical parameters of Well water and wastewater, soil and water samples from them for 20 analysis to the laboratory of the Institute of Agriculture and Natural Resources Research Shiraz was sent.The results of chemical analysis of the important elements of Well water and wastewater (along with Iran's Environmental Protection Organization) is presented in Table 3.According to this table, it can be said that effluent from municipal wastewater treatment Shiraz in all parameters compared to the standard provided by the Environmental Protection Organization of Iran (used in agriculture) are at the limit. The study measured physical and chemical properties of the soil with the help of Soil

25 and Water Laboratory Research Center for Agriculture and Natural Resources Shiraz.Therefore goes on to describe the measured parameters and methods of measuring it is explained briefly:

Soil acidity, after preparing soil samples considered, the acidity of $\mathrm{pH}$ meter by $620 \mathrm{ohm}$ meter was measured. The electrical conductivity of soil: To calculate the conductivity of the device model $646 \mathrm{ohm}$ meter conductivity meter was used. (GarciáGil et al., 2000). Sodium and potassium: Two ions of ammonium acetate normal and to help Corning 410 photometer film

30 device were measured (Khai et al., 2008). Calcium and Magnesium: These two ions were measured by titration with a solution Orsini (Maleki, 2012). Phosphorus: this ion was measured by Olsen method. The five g dry soil, $100 \mathrm{ml}$ half-normal sodium bicarbonate was added to $\mathrm{pH}$ 8.5. After diluting the extract, diluted extract phosphorus by colorimetric spectrophotometer model with the help of Bush and the lamp model 20 was measured (Yu and Jia, 2014). Organic carbon: These ions were measured by using black linen (Maleki, 2012).Nitrogen: Soil nitrogen was measured to the Kjeldahl 35 method. The method of soil nitrogen by sulfuric acid in the presence of a catalyst (copper sulphate, potassium and selenium) oxide and ammonium sulfate becameAnd the nitrogen to ammonia distillation step and then using boric acid and by sulfuric acid to form ammonium become normal 0.005 was the headline. Zinc and iron:The two ions that the heavy elements are analyzed by atomic absorption spectrophotometer equipped with a graphite furnace were measured according to the method described by APHA.( Kaleeem Abbasi et al., 2015).Finally, the study data were calculated by SAS software ver. 9.2 also the charts from Microsoft Excel 2013 was used. It must be noted that the comparison of means were performed by Duncan test.

\section{Discussion}

\subsection{Analysis of variance treatments}

Analysis of variance related to water quality as a result of two main factors, the measured depth (as a subsidiary) and their interactions on the chemical properties of the soil reflects the factThe effect of quality on all traits was meaningfula at the level of one Percent.But the depth of the traits measured in Sodium absorption ratio, sodium, calcium, magnesium, zinc and iron instead of their other traits have a significant effectHowever, the interaction between agents and sub-component attributes a significant effect on phosphorus and carbonate, the other characters is meaningless.

\subsection{Assessment indicators of soil electrical conductivity}

55 The results of the data analysis traits (Table 4) show that the effect of water quality on meaningful attribute is the electrical conductivity.According to the study which is almost 2 times salinity water salinity Well water has been used,Therefore increase in soil salinity by application of wastewater is not expected.In this regard, results of analysis, the average electrical conductivity of the soil after irrigation with well water and treated wastewater that was performed by Duncan test at the level of one Percent,Shows (Table 5), which applies water to the soil to increase soil salinity of the irrigation Well water was of 42.5 percent. 
Solid Earth Discuss., doi:10.5194/se-2017-6, 2017

Manuscript under review for journal Solid Earth

Published: 6 February 2017

(C) Author(s) 2017. CC-BY 3.0 License.

\subsection{Assessment indicators of soil acidity}

The results of the data analysis traits (Table 4) show that the effect of water quality on meaningful attribute is the acidity.

5 Compare the average acidity of the soil quality indicators show that the acidity of the soil by the use of waste water for irrigation to soil acidity, decreased (Table 5).As specified in this way reduce the acidity of the soil in irrigation with treated wastewater to irrigate with well water is about 6 percent. Table 4 show that the effect of depth of the characteristic electrical conductivity meaningful. Therefore comparison of the mean acidity of the soil in the studied depths (Table 5), which with increasing depth, the soil acidity increasesThe increase soil acidity level of about 3.9 percent.Appears to reduce the acidity of

10 the soil at the soil surface to the depths of the reasonThat Since the the soil is favorable conditions for the entry of air into the soil, the rate of decomposition of organic matter including nitrification process, which reduces soil acidity plays(Yazdanpanah et al., 2013; Papadopoulos et al., 2014).

\subsection{The sodium adsorption ratio analysis to evaluate the soil and its components}

Table 4 shows that as The sodium adsorption ratio, sodium, calcium and magnesium are the qualities that only the effect of water quality on them is meaningful.Therefore, these attributes mean comparison analysis was performed by Duncan test at the level of one Percent, show (Table 6) Irrigation with wastewater in order to increase $23.4,64.9,78.3$ and 78.8 percent sodium absorption, sodium, calcium and magnesium led to well water.Acts wastewater rich in sodium, the natural balance change of the soil on the cations leading to the replacement of sodium with other cations, particularly calcium and magnesium in the soil, which thereby increased levels of exchangeable sodium adsorption ratio in the (Meli et al., 2002). Since the amount of The sodium adsorption ratio raw soil is acceptable, The results indicate that irrigation with treated wastewater The sodium adsorption ratio in the city, compared to the initial amount of sodium absorption ratio, increased but this increase is less than the threshold set by the World Food Organization

\subsection{Assessment of soil carbon decomposition and phosphorus}

30 Phosphorus as a nutritional factor contributing to the phenomenon Eutrophication is the transfer of surface water and underground water resources entail reduced quality (Hossein Pur et al., 2009; Magesan et al., 2000; Musinguzi et al., 2015). Table 4 show thatPhosphorus soil carbon characteristics and attributes that in addition to the meaningful effect on the primary and secondary factors, interaction between major and minor factors on these traits is significant.Therefore, these attributes mean comparison analysis was performed by Duncan test at the level of one per cent, is shown (Table 5).

35 Analyze soil characteristics before testing (Table 2) show that the concentration of phosphorus in the soil at depths of 0-30 and $30-60 \mathrm{~cm}$ were 0.0168 and 0.0121 milliequivalent respectively. As well as the chemical properties of water and wastewater analysis used (Table 3) show that the well water used but no phosphorus wastewater containing phosphorus 10.6 milliequivalent.Thus, according to Table 5, the irrigation with well water due to lack of phosphorus in soil depths of 0-30 and $30-60 \mathrm{~cm}$ respectively in 8.3 and 15.7 percent of the phosphorus in the soil before testing decreased.But irrigation with treated wastewater phosphorus in the depths of $0-30$ and $30-60 \mathrm{~cm}$ respectively in the 94.7 and 91.3 percent phosphorus increased soil before testing. Blum et al., (2012) study on land that has been refined over the years by irrigation with sewage water for irrigation-have of the land that had been indicated that a significant amount of phosphorus in the water with wastewater increases. Another issue to be listed on this form, it can be noted that the amount of phosphorus decreases with increasing depthIn this regard, numerous scholar noted that due to the low solubility of phosphorus in the soil, the

45 accumulation of phosphorus in the soil surface layer is substantially (Mojiri,2011; Ameri ,2012). While phosphorus measured at a depth of 0-30 cm soil and irrigated with treated wastewater is statistically the best positionMeasured at a depth of 30-60 $\mathrm{cm}$ and phosphorus treatment and irrigation with treated wastewater by 56.25 percent relative difference in treatment in the best position has been analyzed, statistically at position (b) is located.It should be noted that despite the differences between the two depth measurement 33.8 percent $0-30$ and $30-60 \mathrm{~cm}$ of water for irrigation, these two treatments statistically in a

50 group (c) are located.Table 2 show that the studied soil at depths of $0-30$ and $30-60 \mathrm{~cm} 0.65$ and 1.02 milligrams per liter respectively containing carbonate.As well as the chemical properties of water and wastewater analysis used (Table 3 ) show that the well water used is free of carbon but wastewater contains 2.21 milligrams per liter carbonate. Thus, according to (table 5), it can be said that due to lack of irrigation water for the amount of carbon in the carbonate in water depths of 0-30 and $30-60 \mathrm{~cm}$ respectively in 21.5 and 12.7 percent compared to pre-test the soil carbon declined.But irrigation with treated wastewater carbon content in the depths of 0-30 and 30- $60 \mathrm{~cm}$ respectively in the 38.7 and 44.6 percent increase in soil carbon before testing. Another issue to be listed on this form, it can be noted that the carbon content increases with increasing depthIn this study, measured at a depth of $30-60 \mathrm{~cm}$ soil carbonate and irrigated with treated wastewater is statistically the best positionMeasured at a depth of $0-30 \mathrm{~cm}$ and carbonate treated soil and irrigated with wastewater treatment difference 42.4 percent in the best position has been analyzed, statistically at position (b) is located.The two irrigation wells with depths

60 of 0-30 and 30-60 cm measured on 72.3 and 51.6 percent, respectively, with the difference that in the best position percent compared to treatment was analyzed, statistically respectively, in place of (d) and (c) are located. 
Solid Earth Discuss., doi:10.5194/se-2017-6, 2017

Manuscript under review for journal Solid Earth

Published: 6 February 2017

(c) Author(s) 2017. CC-BY 3.0 License.

The results of the data analysis traits (Table 1) shows that the effect of water quality on the attributes of organic carbon is significant.The comparison of average soil organic carbon analysis of well water and treated wastewater by Duncan test was a percent, shows (Table 5). which apply water to the soil increase the carbon content 67.8 percent organic soil to be well

5 water. Table 1 show that the effect of depth measurement of the quality of soil organic carbon is significant. The comparison of the mean soil organic carbon in the depths studied (Table 5), which with increasing depth, soil organic carbon content is reduced.

\subsection{Assessment indicators of soil nitrogen}

Table 2 show that the studied soil at depths of 0-30 and 30- $60 \mathrm{~cm}$, respectively, 0.046 and 0.021 percent of nitrogen. Also the chemical properties of water and wastewater analysis used (Table 3) show that the well water used is the non-carbonate but containing 2.154 percent of nitrogen wastewater.The results of the data analysis traits (Table 4) show that the effect of water quality on the attributes of nitrogen is significant.The comparison of average soil nitrogen analysis of well water and treated wastewater shows (Table 5), which apply wastewater to the soil to increase soil nitrogen than well water was 68.1 percent.Table 4 show that the effect of depth measurements as soil nitrogen is significant.So comparison shows the average nitrogen soil studied in depth (Table 5), which with increasing depth, soil nitrogen content is reduced, so that the nitrogen in the soil at a depth of 0-30 cm from the 40.9 percent rate increase soil nitrogen at a depth of 30-60 cm. The reason it can be noted that the accumulation of organic matter in surface soil profile, most likely the amount of nitrogen in the soil, due to the decomposition of organic matter and release of ammonium, nitrate, resulting in the phenomenon,cause increased anion in the soil (McLaren et al.,2003).

\subsection{Assessment analysis of heavy metals in soil}

The results of the data analysis traits (Table 4) show that the effect of water quality on the attributes of iron and zinc is significant.So results of analysis, the average iron and zinc soil after irrigation water and wastewater shows (Table 7), which apply water to the soil increased 88.2 and 46.4 percent respectively, iron and zinc soil than water with the well water.

\section{Conclusion}

The study showed With increasing depth of soil acidity increases by 3.9 percent seems to reduce the acidity of the soil at the soil surface to the depths of the reason is that because the conditions for the entry of air into the soil at the soil surface is favorable, the rate of decomposition of organic matter including nitrification process to be followed to reduce the acidity of the soil.With increasing depth of soil electrical conductivity was reduced to 19.6 percent. Because of falling electrical conductivity can-be explained in depth in terms of waste applied to soil, accumulation of organic matter in the soil increases and the lack of opportunity for use of decomposition of organic matter, water infiltration into the soil deep down that whereby the conditions for the accumulation of salt in the soil, So increasing soil salinity in the surface layers of soil.

Irrigation with The treated wastewater increased 42.5 percent soil electrical conductivity of the irrigation water was well.Increase the electrical conductivity of soil in irrigation with wastewater can be linked to high concentrations of cations such as sodium, leading to increased soil electrical conductivity in the wastewater is sentIrrigation with The treated wastewater also reduces soil acidity than 6 percent of the irrigation water was well.Because of falling soil acidity can

45 increase in terms of waste organic materials, formed materials, intermediate acidic gases such as hydrogen sulfide and communication.Irrigation with the treated wastewater increase of 23.4 percent from SAR to irrigation water was well because of the increased sodium absorption ratio can be explained as acts of wastewater rich in sodium, the natural balance of ions in the soil solution disrupts and led to the replacement of sodium with calcium and magnesium cations other especially on the surface of the soil exchangeable which will be followed by SAR. Irrigation with The treated wastewater

50 increased 67.8 and 68.1 percent, respectively, organic carbon and nitrogen to the soil irrigated with well water was treated. With increasing depth of phosphorus and organic carbon in the amount of 56.25 and 44 percent respectively but with the increasing depth of soil carbon to the 42.4 percent increase. With increasing depth of soil nitrogen is reduced to 40.9 percent. The reason it can be noted that the accumulation of organic matter in surface Considering that soil profile is more likely to be high nitrogen content in the soil, due to the decomposition of organic matter and the release of ammonia, which results in a phenomenon nitrate latest increase anion in the soil.

\section{REFERENCES}

60 Abedi, D. C., and Najafi, C.: Use of treated wastewater in agriculture, published by the National Committee on Irrigation and Drainage, 47, 58-78, 2001.

Abedikoopayee, J., Afyoni, M., Mousavi, S. F., Mostafazadeh, M.B., And Bagheri, M.: The effect of sprinkler irrigation and surface treated wastewater on soil salinity, water and wastewater magazine, 45, 2-12, 2003. 
Aggelides, S. M. and Londra, P. A.: Effects of compost produced from town wastes and sewage sludge on the physical properties of a loamy and a clay soil, Bioresource Technol., 71, 253-259, 2000.

Aiello, R., Cirelli, G.L., Consoli, S.: Effects of reclaimed wastewater irrigation on soil and tomato fruits a case study in Sicily (Italy), Agricultural Water Management, 93, 65-72, 2007.

5 Alikhales, D., and Smalzadeh S. M.: The effect of irrigation with the treated wastewater Zinc private cotton plant, Iranian Journal of Soil and Water Research, 2, 235-229, 2010.

Ameri, A.: Study the effects of different ratios of wastewater irrigation on soil physical and chemical characteristics, M.S thesis, Islamic Azad University Kerman Branch, Iran, 45-50, 2012

Asgharzadih, a.: Using effects of sewage sludge and debris hay on some physical and chemical properties of the soil, M.S Thesis, Islamic Azad University Kerman Branch, Iran, 45-50, 2012

Blum, J., Herpin, U., Melfi, A. J., Montes, C. R.: Soil properties in a sugarcane plantation after the application of treated sewage effluent and phosphogypsum in Brazil, Agricultural Water Management, 115, 203-216, 2012.

Gamito, P., Arsenio, A., Faleiro, M.L., Brito, J.M., and Beltrao, J.: The influence of wastewater treatment of irrigation water quality, In: Proceedings of International Workshop on Improved crop quality by nutrient management, Izmir, Turkey, 29 Sep -01 Oct, 267-270, 1999.

Garciá-Gil, J. C., Plaza, C. Soler-Rovira, P., and Polo, A.: Longterm effects of municipal solid waste compost application on soil enzyme activities and microbial biomass, Soil Biol. Biochem., 32, 1914-1919, 2000.

Ghanbari, a., Abedi, J., And TAIE, Jul.: The effect of irrigation with wastewater Zinc yield and quality of wheat and some soil properties in Sistan, Science and Technology of Agriculture and Natural Resources, 4, 54-59,2006.

20 Hossein Pur, O., Haghnia, G., Alizadeh, A., And Fotovat,A .:Changes investigation of chemical quality of raw sewage and waste water passes through the soil StvnᄀHay, Journal of soil and water, 23, 45-56, 2009.

Kaleeem Abbasi, M., Mahmood Tahir, M., Sabir, N., and Khurshid,M.: Impact of the addition of different plant residues on nitrogen mineralization-immobilization turnover and carbon content of a soil incubated under laboratory conditions, Solid Earth, 6, 197-205, doi:10.5194/se-6-197-2015, 2015.

Karak, T., Bhagat R. M., and Bhattacharyya, P.: Municipal solid waste generation, composition, and management: the world scenario, Crit. Rev. Env. Sci. Tec., 42, 1515-1535, 2012.

Karimzadeh, M., Alizadeh, a., Ariamohammadi, M.: The effects of wastewater irrigation on soil saturated hydraulic conductivity, Soil and Water Journal, 26, 47-53, 2012.

Kaschl, A., Romheld, V., and Chen,Y.: The influence of soluble organic matter from municipal solid waste compost on trace metal leaching in calcareous soils, The Science of the Total Environment, 291, 45-57, 2002.

Khai, N., Tuan, P., Vinh, C., Oborn, I.: Effects of using wastewater as nutrient sources on soil chemical properties in peri periurban agricultural systems, Journal of Science, Earth Sciences, 24, 87-95, 2008.

Liaqat, A., and Zamyady, A.: The irrigation methods in agriculture, published by the National Committee on Irrigation and Drainage, 42, 186-194, 2005.

Magesan, G.N., Williamson, J. C., Yeates, G.W., Lloydjones, A.R.: Wastewater C: N ratio effects on soil hydraulic conductivity and potential mechanisms for recovery, Bioresource Technology, 71, 21-27, 2000.

Maleki, a.: The impact of water and treated wastewater and combined sewer Kerman both the physical and chemical properties of soil and drainage, M.S Thesis, Islamic Azad University Kerman Branch, Iran, 15-36, 2012.

McLaren, R.G., Clucas, L.M., Taylor, M.D., Hendry,T.: Leaching of macronutrients and metals from undisturbed soils treated with metal-spiked sewage sludge, Leaching of macronutrients, Australian Journal of Soil Research, 41, 571-588, 2003.

Meli, S., Porto, M., Belligno, A., Bufo, S.A., Mazzatura, A., Scopa, A.: Influence of irrigation with lagooned urban wastewater on chemical and microbiological soil parameters in a citrus orchard under Mediterranean condition, Science of The Total Environment, 285(1-3), 69-77, 2002.

45 Mojiri, A.: Effects of municipal wastewater on physical and chemical properties of saline soil, Journal of Biology, Environ Science, 14, 71-76, 2011.

Musinguzi, P., Ebanyat, P., Tenywa, J. S., Basamba, T. A., Tenywa,M. M., and Mubiru, D.: Precision of farmer-based fertility ratings and soil organic carbon for crop production on a Ferralsol, Solid Earth, 6, 1063-1073, doi:10.5194/se-61063-2015, 2015.

50 Najafi, c., Mousavi, F., and feyzi, M.: The effects of urban The treated wastewater on yield and quality of wheat, Journal of Agricultural Sciences and Natural Resources, 1, 15-25, 2007.

Papadopoulos, A., Bird, N.R.A., Whitmore, A.P., Mooney, S. J.: Does organic management lead to enhanced soil physical quality, Geoderma, 213, 435-443, 2014.

Pescod, M.B.: Wastewater Treatment and Use in Agriculture. FAO United Nations, Rome, Itlay, 5, 125-131, 1992.

Rezapour, S., Samadi, A., Khodaverdiloo H.: Impact of long-term wastewater irrigation on variability of soil attributes along a landscape semi-arid region of Iran, Environmental Earth Sciences, 67, 1713-1723, 2012.

Rohani Shahraki, F., Mahdavi,R., And Rezaei, M.: The effect of irrigation with wastewater on some physical and chemical properties of soil, water and sanitation Journal, 53, 23-29, 2005.

Salehi, N.: Changes the physical and chemical properties of soils irrigated with The treated wastewater urban pistachio, M.S Thesis, Department of Water Engineering martyr Bahonar University, Iran,78-90, 2010.

Salemi, C., and Musharraf, L.: Deficit irrigation impact on the quality and yield of cron , Journal of Agricultural Engineering Research, 26, 71-84, 2006.

Sepaskhah, A.R., Karizi, A.: Effects of alternate use of wastewater and fresh water on soil saturated hydraulic conductivity, Journal of agronomy and soil science, 57,149-158, 2011. 
Solid Earth Discuss., doi:10.5194/se-2017-6, 2017

Manuscript under review for journal Solid Earth

Published: 6 February 2017

(c) Author(s) 2017. CC-BY 3.0 License.

Singh, G., and Bahati,M.: Growth and mineral accumulation in Eucalyptus camaldulensis seedlings irrigated with mixed industrial effluents, Bioresource Technology, 88, 221-228, 2003.

Song,Y.F., Wilke,B.M., Song, X.Y., Gong, P., Zhou, Q.X., Yang, G.F.: Polycyclic aromatic hydrocarbons polychlorinated biphenyls and heavy metals as well as their genotoxicity in soil after long-term wastewater irrigation, Chemosphere, 65, 1859-1868, 2006.

Soudakoure, M.Y., Mermoud, A., Yacouba, H., Boivin, P.: Impacts of irrigation with industrial treated wastewater on soil properties, Geoderma, 201, 31-39, 2013.

Tqvayyan, p., Alizadeh, R.: The impact of wastewater irrigation on soil chemical and physical properties, The journal of Irrigation and Drainage, 42, 2-11, 2007.

10 Xu, J., Wu, L., Chang, A.C., Zhang, Y.: Impact of long-term reclaimed wastewater irrigation on agricultural soils A preliminary assessment, Journal of Hazardous Materials, 183,780-786, 2010.

Yazdanpanah, N., Pazira, E., Neshat, A., Mahmoodabadi, M.,and Rodríguez Sinobas, L.: Reclamation of calcareous saline sodic soil with different amendments (II): Impact on nitrogen,phosphorous and potassium redistribution and on microbial respiration, Agr. Water manage., 120, 39-45, doi:10.1016/j.agwat.2012.08.017, 2013.

15 Yu, Y. and Jia, Z. Q.: Changes in soil organic carbon and nitrogen capacities of Salix cheilophila Schneid along a revegetation chronosequence in semi-arid degraded sandy land of the Gonghe Basin, Tibetan Plateau, Solid Earth, 5, 1045-1054, doi:10.5194/se-5-1045-2014, 2014. 
Solid Earth Discuss., doi:10.5194/se-2017-6, 2017

Manuscript under review for journal Solid Earth

Published: 6 February 2017

(c) Author(s) 2017. CC-BY 3.0 License.

Table 1.Analysis of soil physical characteristics of the area under study

\begin{tabular}{cccccccc}
\hline Real gravity $\left(\mathrm{gr} \mathrm{cm}^{-3}\right)$ & $\begin{array}{c}\text { Apparent specific } \\
\text { weights }\left(\mathrm{gr} \mathrm{cm}^{-3}\right)\end{array}$ & Porosity $(\%)$ & $\begin{array}{c}\text { Soil } \\
\text { texture }\end{array}$ & $\begin{array}{c}\text { Sand } \\
(\%)\end{array}$ & $\begin{array}{c}\text { Silt } \\
(\%)\end{array}$ & $\begin{array}{c}\text { Clay } \\
(\%)\end{array}$ & $\begin{array}{c}\text { Soil } \\
\text { depth } \\
(\mathrm{cm})\end{array}$ \\
\hline 2.67 & 1.42 & 46.8 & $\begin{array}{c}\text { Sandy } \\
\text { loam }\end{array}$ & 57.5 & 28.2 & 14.3 & $0-30$ \\
2.71 & 1.37 & 49.4 & $\begin{array}{c}\text { Sandy } \\
\text { loam }\end{array}$ & 51.3 & 31.9 & 16.8 & $30-60$ \\
\hline
\end{tabular}

5

10

15

20

25

30 
Solid Earth Discuss., doi:10.5194/se-2017-6, 2017

Manuscript under review for journal Solid Earth

Published: 6 February 2017

(c) Author(s) 2017. CC-BY 3.0 License.

Table 2.Chemical analysis of the soil characteristics of the area under study

\begin{tabular}{|c|c|c|c|}
\hline Value & Depth & Unit & Parameter \\
\hline $\begin{array}{l}1.47 \\
1.01\end{array}$ & $\begin{array}{c}0-30 \\
30-60\end{array}$ & ds $m^{-1}$ & $\begin{array}{l}\text { The electrical } \\
\text { conductivity }\end{array}$ \\
\hline $\begin{array}{l}7.1 \\
7.4\end{array}$ & $\begin{array}{c}0-30 \\
30-60\end{array}$ & No Unit & Acidity \\
\hline $\begin{array}{l}1.45 \\
1.37\end{array}$ & $\begin{array}{c}0-30 \\
30-60\end{array}$ & $\mathrm{mEq} \mathrm{L} \mathrm{L}^{-1}$ & Sodium absorption ratio \\
\hline $\begin{array}{l}3.14 \\
2.71\end{array}$ & $\begin{array}{c}0-30 \\
30-60\end{array}$ & $\mathrm{mEq} \mathrm{L} \mathrm{L}^{-1}$ & Sodium \\
\hline $\begin{array}{l}5.85 \\
4.74\end{array}$ & $\begin{array}{c}0-30 \\
30-60\end{array}$ & $\mathrm{mEq} \mathrm{L} \mathrm{L}^{-1}$ & Calcium \\
\hline $\begin{array}{l}3.51 \\
3.22\end{array}$ & $\begin{array}{c}0-30 \\
30-60\end{array}$ & $\mathrm{mEq} \mathrm{L} \mathrm{L}^{-1}$ & Magnesium \\
\hline $\begin{array}{l}0.0168 \\
0.0121\end{array}$ & $\begin{array}{c}0-30 \\
30-60\end{array}$ & $\mathrm{mEq} \mathrm{L} \mathrm{L}^{-1}$ & Phosphorus \\
\hline $\begin{array}{l}0.65 \\
1.02\end{array}$ & $\begin{array}{c}0-30 \\
30-60\end{array}$ & $\mathrm{mg} \mathrm{L}^{-1}$ & Carbonate \\
\hline $\begin{array}{l}0.32 \\
0.18\end{array}$ & $\begin{array}{c}0-30 \\
30-60\end{array}$ & Percentage & Organic carbon \\
\hline $\begin{array}{l}0.046 \\
0.021\end{array}$ & $\begin{array}{c}0-30 \\
30-60\end{array}$ & Percentage & Total nitrogen \\
\hline $\begin{array}{l}0.0001 \\
0.0001\end{array}$ & $\begin{array}{c}0-30 \\
30-60\end{array}$ & $\mathrm{mEq} \mathrm{L} \mathrm{L}^{-1}$ & Iron \\
\hline 0.0003 & $\begin{array}{c}0-30 \\
30-60\end{array}$ & $\mathrm{mEq} \mathrm{L} \mathrm{L}^{-1}$ & Zinc \\
\hline
\end{tabular}


Solid Earth Discuss., doi:10.5194/se-2017-6, 2017

Manuscript under review for journal Solid Earth

Published: 6 February 2017

(c) Author(s) 2017. CC-BY 3.0 License.

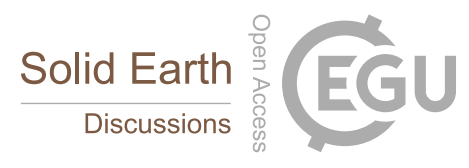

(c) (i)

Table 3.Analyze the chemical properties of Well water and wastewater use and contaminating the standard border ${ }^{1}$

\begin{tabular}{|c|c|c|c|c|}
\hline $\begin{array}{l}\text { The border pollution } \\
\text { standards in agriculture }\end{array}$ & $\begin{array}{l}\text { Wastewater } \\
\text { tested }\end{array}$ & $\begin{array}{c}\text { Well } \\
\text { water }\end{array}$ & Unit & $\begin{array}{l}\text { The measured } \\
\text { parameters }\end{array}$ \\
\hline $6-8.5$ & 6.4 & 6.7 & No Unit & Acidity \\
\hline- & 1.63 & 0.85 & ds $\mathrm{m}^{-1}$ & $\begin{array}{l}\text { The electrical } \\
\text { conductivity }\end{array}$ \\
\hline- & 29.3 & 3.6 & $\mathrm{mEq} \mathrm{L} \mathrm{L}^{-1}$ & Sodium \\
\hline- & 11.2 & 2.4 & $\mathrm{mEq} \mathrm{L} \mathrm{L}^{-1}$ & Calcium \\
\hline 14.1 & 13.7 & 2.1 & $\mathrm{mEq} \mathrm{L} \mathrm{L}^{-1}$ & Magnesium \\
\hline- & 2.03 & 0.85 & $\mathrm{mEq} \mathrm{L} \mathrm{L}^{-1}$ & Potassium \\
\hline- & 8.4 & 2.4 & $\mathrm{mEq} \mathrm{L} \mathrm{L}^{-1}$ & $\begin{array}{l}\text { Sodium absorption } \\
\text { ratio }\end{array}$ \\
\hline- & 10.6 & - & $\mathrm{mEq} \mathrm{L} \mathrm{L}^{-1}$ & Phosphorus \\
\hline- & 0.154 & - & Percentage & nitrogen \\
\hline- & 0.85 & - & Percentage & Total organic carbon \\
\hline- & 2.21 & - & $\mathrm{mg} \mathrm{L}^{-1}$ & Carbonate \\
\hline 3 & 0.29 & - & $\mathrm{mEq} \mathrm{L} \mathrm{L}^{-1}$ & Iron \\
\hline 2 & 0.002 & - & $\mathrm{mEq} \mathrm{L}^{-1}$ & Zinc \\
\hline
\end{tabular}

5

10

15

20 
Solid Earth Discuss., doi:10.5194/se-2017-6, 2017

Manuscript under review for journal Solid Earth

Published: 6 February 2017

(c) Author(s) 2017. CC-BY 3.0 License.

Table 4.Analysis of variance

\begin{tabular}{cccccccc}
\hline Magnesium & Calcium & Sodium & $\begin{array}{c}\text { Sodium } \\
\text { absorption } \\
\text { ratio }\end{array}$ & Acidity & $\begin{array}{c}\text { The electrical } \\
\text { conductivity }\end{array}$ & $\begin{array}{c}\text { Degrees } \\
\text { of } \\
\text { freedom }\end{array}$ & Source Changes \\
\hline 0.0041 & 0.0098 & 0.0012 & 0.0687 & 0.084 & 0.0022 & 2 & Repeat Rep \\
${ }^{* *} 0.91$ & ${ }^{* *} 0.45$ & ${ }^{* *} 0.76$ & ${ }^{* *} 0.81$ & ${ }^{* *} 0.07$ & ${ }^{* *} 0.457$ & 1 & Water Quality A \\
0.59 & 0.39 & 0.22 & 0.93 & 0.51 & 0.846 & 2 & Error(E1) \\
ns 0.32 & ns 0.73 & ns 0.58 & ns 0.24 & ${ }^{* *} 0.079$ & ${ }^{* *} 0.0247$ & 1 & $\begin{array}{c}\text { Measured depth B } \\
\text { reaction AB }\end{array}$ \\
ns 0.01 & ns 0.06 & ns 0.03 & ns 0.18 & ns 0.174 & ns $^{*} 0.0531$ & 1 & Error(E2) \\
0.068 & 0.011 & 0.032 & 0.14 & 0.115 & 0.72 & 3 &
\end{tabular}

Continued Table 4

\begin{tabular}{|c|c|c|c|c|c|c|c|}
\hline Zinc & Iron & $\begin{array}{c}\text { Total } \\
\text { nitrogen }\end{array}$ & $\begin{array}{l}\text { Organic } \\
\text { carbon }\end{array}$ & Carbonate & Phosphorus & $\begin{array}{l}\text { Degrees } \\
\text { of } \\
\text { freedom }\end{array}$ & $\begin{array}{c}\text { Source } \\
\text { Changes }\end{array}$ \\
\hline 0.0328 & 0.0807 & 0.0412 & 0.0589 & 0.0073 & 0.073 & 2 & Repeat Rep \\
\hline${ }^{* *} 0.024$ & ${ }^{* *} 0.057$ & ${ }^{* * *} 0.001$ & ${ }^{* *} 0.321$ & ${ }^{* *} 0.0045$ & ${ }^{* *} 0.56$ & 1 & $\begin{array}{c}\text { Water Quality } \\
\text { A }\end{array}$ \\
\hline 0.072 & 0.094 & 0.014 & 0.808 & 0.325 & 0.54 & 2 & Error(E1) \\
\hline ns 0.068 & ns 0.021 & ${ }^{* *} 0.0047$ & ${ }^{* *} 0.29$ & ${ }^{* *} 0.092$ & ${ }^{* *} 0.71$ & 1 & $\begin{array}{c}\text { Measured } \\
\text { depth B }\end{array}$ \\
\hline ns 0.02 & ns 0.081 & ns 0.0054 & ns 0.048 & ${ }^{* *} 0.018$ & ${ }^{* *} 0.04$ & 1 & reaction $\mathrm{AB}$ \\
\hline 0.079 & 0.061 & 0.0098 & 0.621 & 0.802 & 0.056 & 3 & Error(E2) \\
\hline
\end{tabular}

5 
Solid Earth Discuss., doi:10.5194/se-2017-6, 2017

Manuscript under review for journal Solid Earth

Published: 6 February 2017

(c) Author(s) 2017. CC-BY 3.0 License.

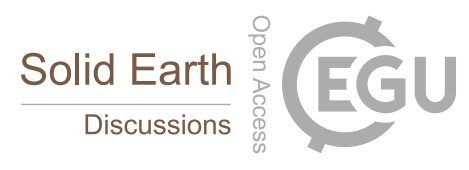

(c) (i)

Table 5.Effects of natural water well \& treated municipal wastewater on chemical soil characteristics

\begin{tabular}{|c|c|c|c|c|c|c|}
\hline Water Quality & $\mathrm{EC}\left(\mathrm{ds} \mathrm{m}^{-1}\right)$ & acidity & $\begin{array}{c}\text { Phosphorus } \\
\left(\mathrm{mEq} \mathrm{L}^{-1}\right)\end{array}$ & $\begin{array}{c}\text { Carbonate } \\
\left(\mathrm{mg} \mathrm{L}^{-1}\right)\end{array}$ & $\begin{array}{c}\text { Organic carbon } \\
\text { (Percentage) }\end{array}$ & $\begin{array}{c}\text { Total nitrogen } \\
\text { (Percentage) }\end{array}$ \\
\hline Water Well & 0.84 & 7.25 & 0.0128 & 0.7 & 0.19 & 0.026 \\
\hline \multicolumn{7}{|l|}{ Study depths (cm) } \\
\hline $0-30$ & 1.275 & 6.89 & 0.167 & 0.785 & 0.5 & 0.066 \\
\hline
\end{tabular}

5

10

15

20

25

30

35

40

45 
Solid Earth Discuss., doi:10.5194/se-2017-6, 2017

Manuscript under review for journal Solid Earth

Published: 6 February 2017

(c) Author(s) 2017. CC-BY 3.0 License.

sold Garat EGG

(c) (i)

Table 6.The effect of water quality on some elements

\begin{tabular}{ccccc}
\hline \multirow{2}{*}{ Water Quality } & \multicolumn{4}{c}{ Elements examined $\left(\mathrm{mEq} \mathrm{L}^{-1}\right)$} \\
\cline { 2 - 5 } & Sodium & Calcium & Magnesium & $\begin{array}{c}\text { The sodium } \\
\text { adsorption ratio }\end{array}$ \\
\hline Water Well & 5.34 & 2.3 & 2.1 & 3.6 \\
The treated wastewater & 15.25 & 10.6 & 9.9 & 4.7 \\
\hline
\end{tabular}

5

10

15

20

25

30

35

40

45

50

55 
Solid Earth Discuss., doi:10.5194/se-2017-6, 2017

Manuscript under review for journal Solid Earth

Published: 6 February 2017

(c) Author(s) 2017. CC-BY 3.0 License.

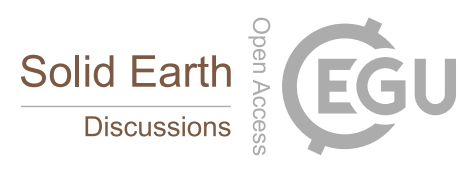

(c) (i)

Table 7.Impact of Water Quality on heavy metals

\begin{tabular}{ccc}
\hline \multirow{2}{*}{ Water Quality } & \multicolumn{2}{c}{ Elements examined $\left(\mathrm{mEq} \mathrm{L}^{-1}\right)$} \\
\cline { 2 - 3 } & Iron & Zinc \\
\hline Water Well & 0.0001 & 0.003 \\
wastewater & 0.00085 & 0.0056 \\
\hline
\end{tabular}

5 